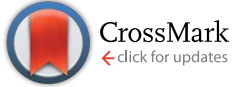

Cite this: J. Mater. Chem. C, 2014, 2 7047

Received 4th June 2014

Accepted 9th July 2014

DOI: $10.1039 / c 4 t c 01171 f$

www.rsc.org/MaterialsC

\title{
Bright and stable light-emitting electrochemical cells based on an intramolecularly $\pi$-stacked, 2- naphthyl-substituted iridium complex $\dagger$
}

\author{
Gabriel E. Schneider, ${ }^{a}$ Antonio Pertegás, ${ }^{b}$ Edwin C. Constable, ${ }^{a}$ \\ Catherine E. Housecroft, ${ }^{\star a}$ Nik Hostettler, ${ }^{a}$ Collin D. Morris, ${ }^{a}$ Jennifer A. Zampese, ${ }^{a}$ \\ Henk J. Bolink, ${ }^{b}$ José M. Junquera-Hernández, ${ }^{b}$ Enrique Orti ${ }^{* b}$ and Michele Sessolo ${ }^{b}$
}

\begin{abstract}
The synthesis and characterization of a new cationic bis-cyclometallated iridium(III) complex and its use in solid-state light-emitting electrochemical cells (LECs) are described. The complex $\left[\operatorname{lr}(p p y)_{2}\left(\operatorname{Naphbpy}_{3}\right]\left[\mathrm{PF}_{6}\right]\right.$, where Hppy = 2-phenylpyridine and Naphbpy = 6-(2-naphthyl)-2,2'-bipyridine, incorporates a pendant 2naphthyl unit that $\pi$-stacks face-to-face with the adjacent ppy ${ }^{-}$ligand and acts as a peripheral bulky group. The complex presents a structureless emission centred around 595-600 nm both in solution and in thin film with relatively low photoluminescence quantum yields compared with analogous systems. Density functional theory calculations support the charge transfer character of the emitting triplet state and rationalize the low quantum yields in terms of a ligand-centred triplet localized on the 2-naphthyl unit that lies close in energy to the emitting state. LECs incorporating the $\left[\operatorname{lr}(\mathrm{ppy})_{2}(\mathrm{Naphbpy})\right]\left[\mathrm{PF}_{6}\right]$ complex as the electroluminescent material are driven using a pulsed current operation mode and show high luminance, exceeding $300 \mathrm{~cd} \mathrm{~m}^{-2}$, and exceptional stabilities.
\end{abstract}

\section{Introduction}

The successful market entry of displays based on organic lightemitting diodes (OLEDs) testifies the maturity of the technology in terms of both stability and efficiency. The latter is achieved through the use of different materials designed to comply with specific functions, such as hole/electron injection and transport, exciton formation and light emission. ${ }^{1-3}$ These materials are stacked in multilayer structures obtained through vacuum deposition, and use low work function cathodes that have to be protected from the environment through rigorous encapsulation to avoid fast degradation. ${ }^{4}$ The corresponding costs are compatible with the display market but need to be substantially reduced for lighting applications. For this reason, simple solution-processed OLEDs are still the focus of considerable attention. ${ }^{5-7}$ Light-emitting electrochemical cells (LECs) are also solution processed and consist of a single electroactive layer of an ionic

\footnotetext{
${ }^{a}$ Department of Chemistry, University of Basel, Spitalstrasse 51, CH-4056 Basel, Switzerland. E-mail: catherine.housecroft@unibas.ch

${ }^{b}$ Instituto de Ciencia Molecular, Universidad de Valencia, ES-46980 Paterna, Valencia, Spain.E-mail: enrique.orti@uv.es

$\dagger$ Electronic supplementary information (ESI) available: Fig. S1 CV of $\left[\operatorname{Ir}(\mathrm{ppy})_{2}(\mathrm{Naphbpy})\right]\left[\mathrm{PF}_{6}\right]$; Table $\mathrm{S} 1$ experimental and calculated bond parameters of $\left[\operatorname{Ir}(\mathrm{ppy})_{2}(\mathrm{Naphbpy})\right]^{+}$; Fig. S2 optimized structure of the transition state connecting conformers 1 and 2; Fig. S3 optimized bond lengths calculated for the pendant 2-naphthyl group. CCDC 972526. For ESI and crystallographic data in CIF or other electronic format see DOI: 10.1039/c4tc01171f
}

organic semiconductor placed between two electrodes. ${ }^{8}$ The high concentration of ions assists both charge injection and transport, allowing the use of stable metal electrodes and thus paving the way to a new generation of low-cost lighting sources. ${ }^{9,10}$

Ionic transition-metal complexes (iTMCs) are among the most studied active species for LECs. ${ }^{11}$ They exhibit high photoluminescence quantum yield (PLQY) and the emission can be easily tuned through ligand design. iTMCs can be deposited as pure layers in electroluminescent devices since the complex by itself assists charge injection and transport and is the active luminescent species. ${ }^{12}$ The simplest LEC consists of a single active layer composed entirely of an iTMC balanced by small mobile counter anions such as $\left[\mathrm{PF}_{6}\right]^{-}$or $\left[\mathrm{BF}_{4}\right]^{-}$.

Cationic heteroleptic iridium(III) complexes with the structure $\left[\operatorname{Ir}\left(\mathrm{C}^{\wedge} \mathrm{N}\right)_{2}\left(\mathrm{~N}^{\wedge} \mathrm{N}\right)\right]^{+}$, where $\mathrm{C}^{\wedge} \mathrm{N}$ is an anionic cyclometallated ligand and $\mathrm{N}^{\wedge} \mathrm{N}$ a neutral diimine ancillary ligand, represent the most promising candidates for long-living, stable LECs. While the optoelectronic properties can be directly tuned by varying the type of ligands and the electron affinity of their substituents, the performances in devices (i.e., the stability, efficiency and turn-on time) cannot be straightforwardly predicted. Some trends, however, exist and a few general design rules have been proposed. The introduction of bulky substituents on the periphery of the iTMC allows for an increased spatial separation between the emissive centers in a pure film and thereby for a reduction of the exciton quenching. ${ }^{13,14}$ This effect enhances the PLQY of the film and therefore the overall device efficiency. On 
the other hand, the device lifetime has been correlated with the reactivity of the complex in the excited state, where nucleophilic molecules are able to react with the iTMCs leading to the formation of quenching species and to fast device degradation. ${ }^{15,16}$ This phenomena can be limited by introducing intramolecular $\pi-\pi$ interactions within the ligands, which close the structure of the complex and protect the metal center from nucleophilic substitution with water or residual solvent molecules in the film. ${ }^{17}$ An illustrative example is the incorporation of a pendant phenyl ring adjacent to one $\mathrm{N}$-donor of the chelating $\mathrm{N}^{\wedge} \mathrm{N}$ ligand, which results in a face-to-face $\pi$-stacking with one of the cyclometallating $\mathrm{C}^{\wedge} \mathrm{N}$ ligands. ${ }^{18}$ This structural feature has an enormous impact on the device lifetime, which increases from a few hours to several months. The control of both inter- and intramolecular interactions in iTMCs has led to a new generation of LECs with enhanced lifetime and efficiency, with potential practical application in solid-state lighting. ${ }^{19}$

Within this perspective, we have synthesized and characterized the hexafluoridophosphate $\left[\mathrm{PF}_{6}\right]^{-}$salt of a heteroleptic iridium(III) complex with the formula $\left[\operatorname{Ir}(\mathrm{ppy})_{2}(\mathrm{Naphbpy})\right]\left[\mathrm{PF}_{6}\right]$, where Hppy is 2-phenylpyridine and Naphbpy is the 6-(2naphthyl)-2,2'-bipyridine ancillary ligand. The purpose of the 2naphthyl substituent on the bpy ligand is twofold: (i) to $\pi$-stack with the ppy ${ }^{-}$ligands, stabilizing the geometry of the complex in the excited state, and (ii) to act as a bulky group on the periphery of the complex thus reducing the intermolecular interactions. The $\left[\operatorname{Ir}(\mathrm{ppy})_{2}(\mathrm{Naphbpy})\right]\left[\mathrm{PF}_{6}\right]$ complex was used to prepare single-layer LECs and its structural features resulted in a high device stability and efficiency.

\section{Experimental section}

General

A Bruker Avance III-500 NMR spectrometer was used to record ${ }^{1} \mathrm{H}$ and ${ }^{13} \mathrm{C}$ NMR spectra; chemical shifts are referenced to residual solvent peaks with respect to $\delta$ (TMS) $=0 \mathrm{ppm}$. Electrospray ionization (ESI) mass spectra were recorded using a Bruker esquire $3000^{\text {plus }}$ instrument. Solution electronic absorption spectra were recorded on an Agilent 8453 spectrophotometer, emission spectra using a Shimadzu RF-5301 PC spectrofluorometer and FT-IR spectra with a Shimadzu 8400 S instrument with Golden Gate accessory (solid samples). Solution quantum yields were measured using a Hamamatsu absolute PL quantum yield spectrometer C11347 Quantaurus-QY, and lifetimes were measured using a Hamamatsu Compact Fluorescence Lifetime Spectrometer C11367 Quantaurus-Tau; an LED light source with excitation wavelength of $280 \mathrm{~nm}$ was used. Microwave reactions were carried out in a Biotage Initiator 8 reactor.

Electrochemical measurements were recorded using a $\mathrm{CH}$ Instruments 900B potentiostat using glassy carbon, a platinum wire and a silver wire as the working, counter and reference electrodes, respectively. Samples were dissolved in HPLC grade $\operatorname{MeCN}\left(\approx 10^{-4} \mathrm{~mol} \mathrm{dm}^{-3}\right)$ containing $0.1 \mathrm{~mol} \mathrm{dm}^{-3}\left[{ }^{n} \mathrm{Bu}_{4} \mathrm{~N}\right]\left[\mathrm{PF}_{6}\right]$ as the supporting electrolyte; all solutions were degassed with argon. $\mathrm{Cp}_{2} \mathrm{Fe}$ was used as an internal reference.

1-(2-Naphthyl)-3-dimethylamino propan-1-one was prepared according to a literature method. ${ }^{20}$

\section{6-(2-Naphthyl)-2,2'-bipyridine (Naphbpy)}

The synthesis of Naphbpy has previously been described. ${ }^{21}$ However, we find the following method convenient although the yield is lower than that reported. 1-(2-Naphthyl)-3-dimethylaminopropan-1-one (425 mg, $1.61 \mathrm{mmol}$ ), 1-(2-oxo-2-(2-pyridyl) ethyl)pyridine-1-ium iodide (525 mg, $1.61 \mathrm{mmol})$ and $\mathrm{NH}_{4} \mathrm{OAc}$ (10 eq.) were combined in EtOH $(20 \mathrm{~mL})$ and the mixture was heated overnight at reflux. The resulting brown oily liquid was reduced in volume, dissolved in water and extracted into $\mathrm{CH}_{2} \mathrm{Cl}_{2}$ $(3 \times 25 \mathrm{~mL})$. The organic solvent was evaporated and the crude material was purified twice by column chromatography (silica, $\mathrm{CH}_{2} \mathrm{Cl}_{2}$ changing to $\mathrm{CH}_{2} \mathrm{Cl}_{2}: \mathrm{MeOH} \quad 100: 1.5$ and $\left.\mathrm{CH}_{2} \mathrm{Cl}_{2}: \mathrm{MeOH} 100: 0.5\right)$. Naphbpy was isolated as a white solid (65.1 mg, $0.231 \mathrm{mmol}, 14.3 \%)$. The ${ }^{1} \mathrm{H}$ NMR spectrum has previously been reported in DMSO- $d_{6} \cdot{ }^{21}{ }^{1} \mathrm{H}$ NMR $(500 \mathrm{MHz}$, $\mathrm{CD}_{2} \mathrm{Cl}_{2}, 295 \mathrm{~K}$, atom labelling as in Scheme 1) $\delta / \mathrm{ppm} 8.71(\mathrm{~m}$, $\left.2 \mathrm{H}, \mathrm{H}^{\mathrm{E} 3+\mathrm{E} 6}\right), 8.64\left(\mathrm{~d}, J=1.2 \mathrm{~Hz}, 1 \mathrm{H}, \mathrm{H}^{\mathrm{G} 1}\right), 8.42(\mathrm{dd}, J=6.5,2.3$ $\left.\mathrm{Hz}, 1 \mathrm{H}, \mathrm{H}^{\mathrm{F} 3}\right), 8.36\left(\mathrm{dd}, J=8.6,1.8 \mathrm{~Hz}, 1 \mathrm{H}, \mathrm{H}^{\mathrm{G} 3}\right), 8.04-7.88$ (overlapping $\left.\mathrm{m}, 6 \mathrm{H}, \mathrm{H}^{\mathrm{E} 4+\mathrm{F} 4+\mathrm{F} 5+\mathrm{G} 4+\mathrm{G} 5+\mathrm{G} 8}\right), 7.54\left(\mathrm{~m}, 2 \mathrm{H}, \mathrm{H}^{\mathrm{G} 6+\mathrm{G} 7}\right)$, 7.37 (ddd, $\left.J=7.5,4.7,1.2 \mathrm{~Hz}, 1 \mathrm{H}, \mathrm{H}^{\mathrm{E} 5}\right) .{ }^{13} \mathrm{C}\left\{{ }^{1} \mathrm{H}\right\} \mathrm{NMR}(126 \mathrm{MHz}$, $\left.\mathrm{CD}_{2} \mathrm{Cl}_{2}, 295 \mathrm{~K}\right) \delta / \mathrm{ppm} 156.6\left(\mathrm{C}^{\mathrm{E} 2}\right), 156.4\left(\mathrm{C}^{\mathrm{F} 6}\right), 156.2\left(\mathrm{C}^{\mathrm{F} 2}\right), 149.6$ $\left(\mathrm{C}^{\mathrm{E} 6}\right), 138.3\left(\mathrm{C}^{\mathrm{F} 4}\right), 137.2\left(\mathrm{C}^{\mathrm{E} 4}\right), 136.8\left(\mathrm{C}^{\mathrm{G} 4 \mathrm{a}+\mathrm{G} 8 \mathrm{a}}\right), 134.0\left(\mathrm{C}^{\mathrm{G} 2}\right), 128.9$ $\left(\mathrm{C}^{\mathrm{G} 8}\right), 128.1\left(\mathrm{C}^{\mathrm{G} 4+\mathrm{G} 5}\right), 126.9\left(\mathrm{C}^{\mathrm{G} 6+\mathrm{G} 7}\right), 125.1\left(\mathrm{C}^{\mathrm{G} 3}\right), 124.3\left(\mathrm{C}^{\mathrm{E} 5}\right)$, $121.5\left(\mathrm{C}^{\mathrm{E} 3}\right), 120.9\left(\mathrm{C}^{\mathrm{F} 5}\right)$.

\section{$\left[\operatorname{Ir}(\text { ppy })_{2}(\right.$ Naphbpy $\left.)\right]\left[\mathrm{PF}_{6}\right]$}

A yellow suspension of $\left[\operatorname{Ir}_{2}(\mathrm{ppy})_{4}(\mu-\mathrm{Cl})_{2}\right](107 \mathrm{mg}, 0.100 \mathrm{mmol})$ and Naphbpy $(56.8 \mathrm{mg}, 0.201 \mathrm{mmol})$ in $\mathrm{MeOH}(15 \mathrm{~mL})$ was heated in a microwave reactor at $120^{\circ} \mathrm{C}$ for $2 \mathrm{~h}(P=8$ bar $)$. The yellow solution was allowed to cool to room temperature, and then an excess of $\mathrm{NH}_{4} \mathrm{PF}_{6}(326 \mathrm{mg}, 2.00 \mathrm{mmol})$ was added. The mixture was stirred for $30 \mathrm{~min}$ at room temperature and then evaporated to dryness. The crude yellow material was purified twice by column chromatography (Fluka Silica 60; $\mathrm{CH}_{2} \mathrm{Cl}_{2}$ changing to $\left.\mathrm{CH}_{2} \mathrm{Cl}_{2}: \mathrm{MeOH} 100: 2\right)$. [ $\left.\operatorname{Ir}(\mathrm{ppy})_{2}(\mathrm{Naphbpy})\right]\left[\mathrm{PF}_{6}\right]$ was isolated as a yellow solid ( $92.3 \mathrm{mg}, 0.099 \mathrm{mmol}, 49.6 \%)$. Addition of $\left[\mathrm{Bu}_{4} \mathrm{~N}\right]\left[\mathrm{PF}_{6}\right]$ to a $\mathrm{CD}_{2} \mathrm{Cl}_{2}$ solution of the complex resulted in no shift of the signals arising from protons $\mathrm{H}^{\mathrm{E} 3}$ and $\mathrm{H}^{\mathrm{F} 3}$ confirming the lack of chloride impurity. ${ }^{22}{ }^{1} \mathrm{H}$ NMR (500 $\left.\mathrm{MHz}, \mathrm{CD}_{2} \mathrm{Cl}_{2}, 295 \mathrm{~K}\right) \delta / \mathrm{ppm} 8.56\left(\mathrm{dd}, J=8.1,1.3 \mathrm{~Hz}, 1 \mathrm{H}, \mathrm{H}^{\mathrm{F} 3}\right)$, $8.52\left(\mathrm{~d}, J=8.2 \mathrm{~Hz}, 1 \mathrm{H}, \mathrm{H}^{\mathrm{F} 3}\right), 8.26\left(\mathrm{t}, J=7.9 \mathrm{~Hz}, 1 \mathrm{H}, \mathrm{H}^{\mathrm{F}}\right), 8.12$ $\left(\mathrm{m}, 1 \mathrm{H}, \mathrm{H}^{\mathrm{E} 4}\right), 7.91\left(\mathrm{~m}, 1 \mathrm{H}, \mathrm{H}^{\mathrm{E} 6}\right)$ overlapping with 7.88

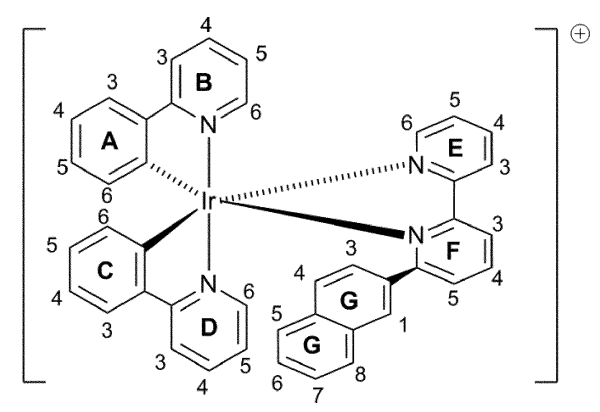

Scheme 1 Structure of the $\left[\operatorname{Ir}(\text { ppy })_{2}(\mathrm{Naphbpy})\right]^{+}$cation and atom numbering for NMR assignments. 
$\left(\mathrm{m}, 1 \mathrm{H}, \mathrm{H}^{\mathrm{B} 4 / \mathrm{D} 4}\right), 7.80\left(\mathrm{~m}, 1 \mathrm{H}, \mathrm{H}^{\mathrm{B} 3 / \mathrm{D} 3}\right)$ overlapping with $7.77(\mathrm{~m}$, $\left.1 \mathrm{H}, \mathrm{H}^{\mathrm{B} 4 / \mathrm{D} 4}\right), 7.73\left(\mathrm{~d}, J=5.7 \mathrm{~Hz}, 1 \mathrm{H}, \mathrm{H}^{\mathrm{D} 6}\right), 7.66\left(\mathrm{br}, \mathrm{H}^{\mathrm{D} 3}\right)$ overlapping with $7.64\left(\mathrm{dd}, J=7.8,1.2 \mathrm{~Hz}, 1 \mathrm{H}, \mathrm{H}^{\mathrm{G} 7}\right), 7.60(\mathrm{dd}, J=7.7$, $1.2 \mathrm{~Hz}, 1 \mathrm{H}, \mathrm{H}^{\mathrm{F} 5}$ ), $7.50\left(\mathrm{dd}, J=7.7,1.4 \mathrm{~Hz}, 1 \mathrm{H}, \mathrm{H}^{\mathrm{A} 3}\right), 7.48-7.37$ (overlapping $\mathrm{m}, 3 \mathrm{H}, \mathrm{H}^{\mathrm{B} 6+\mathrm{E} 5+\mathrm{G} 6}$ ), $7.32\left(\mathrm{v} . \mathrm{br}, \mathrm{H}^{\mathrm{G} 1 / \mathrm{G} 3 / \mathrm{G} 4 / \mathrm{G} 5 / \mathrm{G} 8}\right), 7.23$ (v. br, H $\left.\mathrm{H}^{\mathrm{G} 1 / \mathrm{G} 3 / \mathrm{G} 4 / \mathrm{G} 5 / \mathrm{G} 8}\right), 7.11\left(\mathrm{~m}, 1 \mathrm{H}, \mathrm{H}^{\mathrm{B} 5 / \mathrm{D} 5}\right), 7.08\left(\mathrm{~m}, 1 \mathrm{H}, \mathrm{H}^{\mathrm{B} 5 / \mathrm{D} 5}\right)$, $6.92\left(\mathrm{~m}, 1 \mathrm{H}, \mathrm{H}^{\mathrm{A} 4}\right), 6.78\left(\mathrm{~m}, 1 \mathrm{H}, \mathrm{H}^{\mathrm{A} 5}\right), 6.53$ (v. br, $\left.\mathrm{H}^{\mathrm{C} 3}\right), 6.03$ (v. br, $\left.\mathrm{H}^{\mathrm{C} 5}\right), 5.98\left(\mathrm{br} \mathrm{t}, \mathrm{J}=7.5 \mathrm{~Hz}, 1 \mathrm{H}, \mathrm{H}^{\mathrm{C} 4}\right), 5.89\left(\mathrm{~m}, 1 \mathrm{H}, \mathrm{H}^{\mathrm{A} 6}\right), 5.49(\mathrm{br}$ $\left.\mathrm{d}, 1 \mathrm{H}, \mathrm{H}^{\mathrm{C} 6}\right)$; not all signals for $\mathrm{H}^{\mathrm{G} 1 / \mathrm{G} 3 / \mathrm{G} 4 / \mathrm{G} 5 / \mathrm{G} 8}$ observed. ${ }^{13} \mathrm{C} \mathrm{NMR}$ $\left(126 \mathrm{MHz}, \mathrm{CD}_{2} \mathrm{Cl}_{2}, 295 \mathrm{~K}\right) \delta /$ ppm $169.1\left(\mathrm{C}^{\mathrm{D} 2}\right), 167.5\left(\mathrm{C}^{\mathrm{B} 2}\right), 166.2$ $\left(\mathrm{C}^{\mathrm{F} 6}\right), 157.2\left(\mathrm{C}^{\mathrm{E} 2}\right), 150.8\left(\mathrm{C}^{\mathrm{E} 6}\right), 149.3\left(\mathrm{C}^{\mathrm{B} 6 / \mathrm{D} 6}\right), 149.2\left(\mathrm{C}^{\mathrm{B} 6 / \mathrm{D} 6}\right), 146.9$ $\left(\mathrm{C}^{\mathrm{A} 1}\right), 143.3\left(\mathrm{C}^{\mathrm{A} 2}\right), 140.0\left(\mathrm{C}^{\mathrm{F} 4}\right), 139.7\left(\mathrm{C}^{\mathrm{E} 4}\right), 138.6\left(\mathrm{C}^{\mathrm{B} 4 / \mathrm{D} 4}\right), 138.3$ $\left(\mathrm{C}^{\mathrm{B} 4 / \mathrm{D} 4}\right), 131.2\left(\mathrm{C}^{\mathrm{C} 6}\right), 131.1\left(\mathrm{C}^{\mathrm{A} 5}\right), 130.5\left(\mathrm{C}^{\mathrm{A} 6}\right), 130.4\left(\mathrm{C}^{\mathrm{F} 5}\right), 128.1$ $\left(\mathrm{C}^{\mathrm{E} 5}\right), 127.9\left(\mathrm{C}^{\mathrm{G} 7}\right), 127.0\left(\mathrm{C}^{\mathrm{G} 6}\right), 125.4\left(\mathrm{C}^{\mathrm{E} 3}\right), 125.0\left(\mathrm{C}^{\mathrm{A} 3}\right), 123.7$ $\left(\mathrm{C}^{\mathrm{B} 5 / \mathrm{D} 5}\right), 124.0\left(\mathrm{C}^{\mathrm{F} 3}\right), 123.1\left(\mathrm{C}^{\mathrm{A} 4}\right), 122.7\left(\mathrm{C}^{\mathrm{B} 5 / \mathrm{D} 5}\right), 120.5\left(\mathrm{C}^{\mathrm{C} 4}\right), 120.4$ $\left(\mathrm{C}^{\mathrm{B} 3 / \mathrm{D} 3}\right), 120.2\left(\mathrm{C}^{\mathrm{B} 3 / \mathrm{D} 3}\right) ; \mathrm{C}^{\mathrm{C} 1 / \mathrm{C} 2 / \mathrm{C} 3 / \mathrm{C} 5 / \mathrm{G} 1 / \mathrm{G} 2 / \mathrm{G} 3 / \mathrm{G} 4 \mathrm{G} 4 \mathrm{a} / \mathrm{G} 5 / \mathrm{G} 8 / \mathrm{G} 8 \mathrm{a}}$ not resolved. IR (solid, $\nu / \mathrm{cm}^{-1}$ ) $3998(\mathrm{~m}), 3043(\mathrm{w}), 1667$ (w), 1607 (s), 1582 (m), 1558 (m), 1551 (m), 1477 (s), 1447 (m), 1440 (m), 1419 (m), 1317 (w), 1269 (w), 1230 (m), 1164 (m), 1161 (m), $1124(\mathrm{w})$, 1063 (w), 1031 (m), 1010 (w), 949 (w), 885 (w), 830 (s), 777 (m), 754 (s), 746 (s), 735 (s), 728 (s), 697 (w), 668 (m), 631 (m), 603 (s). ESI-MS $m / z 783.2\left[\mathrm{M}-\mathrm{PF}_{6}\right]^{+}$(calc. 783.2). UV-Vis $\lambda / \mathrm{nm}\left(\varepsilon / \mathrm{dm}^{3}\right.$ $\left.\mathrm{mol}^{-1} \mathrm{~cm}^{-1}\right)\left(\mathrm{CH}_{2} \mathrm{Cl}_{2}, 1.00 \times 10^{-5} \mathrm{~mol} \mathrm{dm}^{-3}\right) 271$ (44200), 313 (22100, sh), 387 (4800). Emission $\left(\mathrm{CH}_{2} \mathrm{Cl}_{2}, 1.00 \times 10^{-5} \mathrm{~mol}\right.$ $\left.\mathrm{dm}^{-3}, \lambda_{\mathrm{ex}}=275 \mathrm{~nm}\right) \lambda_{\mathrm{em}}=598 \mathrm{~nm}$. Found: C 53.96, H 3.39, N 6.44; $\mathrm{C}_{42} \mathrm{H}_{30} \mathrm{IrN}_{4} \mathrm{PF}_{6}$ requires C 54.37, $\mathrm{H} 3.26, \mathrm{~N} 6.04 \%$.

\section{Crystallography}

Data were collected on a Bruker-Nonius KappaAPEX diffractometer with data reduction, solution and refinement using APEX2 $^{23}$ and SHELXL97. ${ }^{24}$ The ORTEP-style diagram was generated using Mercury v. 3.0, and this program was also used for structural analysis. ${ }^{25,26}$

\section{$\left[\operatorname{Ir}(\text { ppy })_{2}(\right.$ Naphbpy $\left.)\right]\left[\mathrm{PF}_{6}\right]$}

$\mathrm{C}_{42} \mathrm{H}_{30} \mathrm{~F}_{2} \mathrm{IrN}_{4} \mathrm{P}, M=927.89$, yellow block, orthorhombic, space group Ccca, $a=23.8655(10), b=34.2298(10), c=17.5645(5) \AA$, $U$ $=14348.6(8) \AA^{3}, Z=16, D_{c}=1.718 \mathrm{Mg} \mathrm{m}^{-3}, \mu(\mathrm{Cu}-\mathrm{K} \alpha)=8.224$ $\mathrm{mm}^{-1}, T=123 \mathrm{~K}$. Total 108787 reflections, 6518 unique, $R_{\text {int }}=$ 0.0482 . Refinement of 5227 reflections (510 parameters) with $I>$ $2 \sigma(I)$ converged at final $R_{1}=0.0439\left(R_{1}\right.$ all data $\left.=0.0556\right), w R_{2}=$ $0.1084\left(w R_{2}\right.$ all data $\left.=0.1222\right)$, gof $=1.083$, CCDC 972526. $\dagger$

\section{Computational details}

Density functional calculations (DFT) were carried out with the D.01 revision of the Gaussian 09 program package ${ }^{27}$ using Becke's three-parameter B3LYP exchange-correlation functional ${ }^{28,29}$ together with the $6-31 \mathrm{G}^{* *}$ basis set for $\mathrm{C}, \mathrm{H}$, and $\mathrm{N},{ }^{30}$ and the "double- $\zeta$ " quality LANL2DZ basis set for the Ir element. ${ }^{31}$ The geometries of the singlet ground state and of the lowest-energy triplet states were fully optimized without imposing any symmetry restriction. All the calculations were performed in the presence of the solvent $\left(\mathrm{CH}_{2} \mathrm{Cl}_{2}\right)$. Solvent effects were considered within the self-consistent reaction field (SCRF) theory using the polarized continuum model (PCM) approach. ${ }^{32-34}$ Time-dependent DFT (TD-DFT) calculations of the lowest-lying 20 triplets were performed in the presence of the solvent at the minimum-energy geometry optimized for the ground state. The geometries of the two lowest-energy triplets $\left(\mathrm{T}_{1}\right.$ and $\left.\mathrm{T}_{2}\right)$ were first optimized at the spin-unrestricted UB3LYP level and afterwards reoptimized at the more accurate TD-DFT level.

\section{Results and discussion}

\section{Synthesis and single crystal structure of $\left[\operatorname{Ir}(\mathrm{ppy})_{2}(\mathrm{Naphbpy})\right]$} $\left[\mathrm{PF}_{6}\right]$

The ligand Naphbpy was prepared by Kröhnke methodology, ${ }^{35}$ rather than by the Jameson literature procedure. ${ }^{21}\left[\operatorname{Ir}(\mathrm{ppy})_{2}\right.$ (Naphbpy)][ $\left.\mathrm{PF}_{6}\right]$ was prepared using the proven methodology of treating the $\left[\operatorname{Ir}_{2}(\mathrm{ppy})_{4}(\mu-\mathrm{Cl})_{2}\right]$ dimer with two equivalents of Naphbpy. ${ }^{36}$ After work-up, $\left[\operatorname{Ir}(\mathrm{ppy})_{2}(\mathrm{Naphbpy})\right]\left[\mathrm{PF}_{6}\right]$ was isolated in $49.6 \%$ yield. The base peak in the electrospray mass spectrum $\left(m / z\right.$ 783.2) arose from the $\left[\mathbf{M}-\mathrm{PF}_{6}\right]^{+}$ion, and exhibited the characteristic isotope pattern of iridium. Single crystals of $\left[\operatorname{Ir}(\text { ppy })_{2}(\mathrm{Naphbpy})\right]\left[\mathrm{PF}_{6}\right]$ grew upon slow evaporation of solvent from a $\mathrm{CH}_{2} \mathrm{Cl}_{2}$ solution of the compound. The complex crystallizes in the orthorhombic space group Ccca and the structure of the $\Lambda$-[Ir(ppy $)_{2}($ Naphbpy $\left.)\right]^{+}$ion present in the asymmetric unit is shown in Fig. 1. The chirality arises from the presence of the three chelating ligands bound to the octahedral Ir1 atom, and both enantiomers are present in the lattice. As is typical of a $\left[\operatorname{Ir}\left(\mathrm{C}^{\wedge} \mathrm{N}\right)_{2}\left(\mathrm{~N}^{\wedge} \mathrm{N}\right)\right]^{+}$complex, the N-donors of the two cyclometalled $\mathrm{ppy}^{-}$ligands are trans to one another. Each $\mathrm{ppy}^{-}$ ligand is close to planar (angles between the least squares planes of the phenyl and pyridine rings are 4.2 and $7.0^{\circ}$ ). The bpy domain is distorted (angle between the two pyridine rings $=$ $18.5^{\circ}$ ) and the 2-naphthyl unit is twisted through $60.3^{\circ}$ with respect to the pyridine ring to which it is connected. The

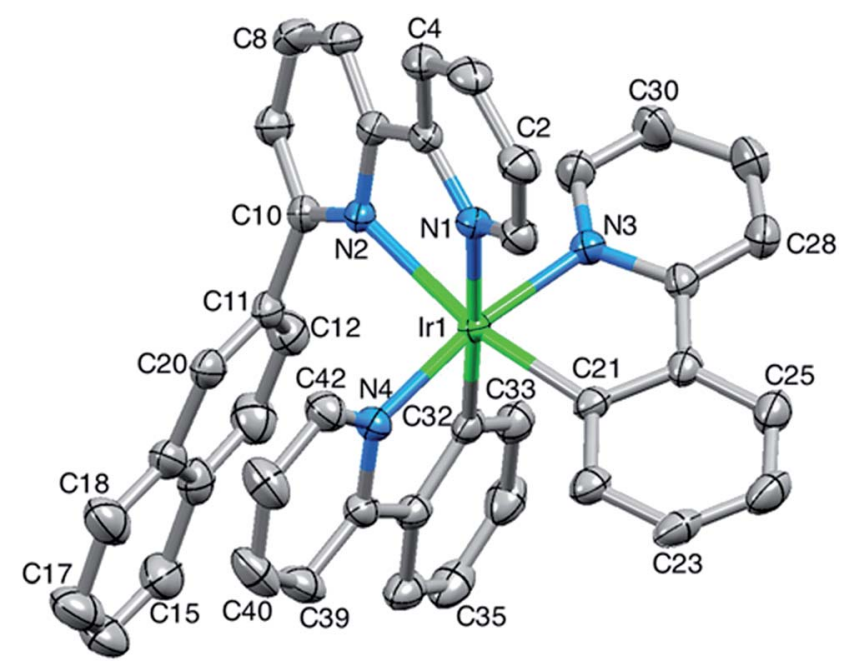

Fig. 1 Structure of the $\Lambda$-[Ir(ppy $)_{2}($ Naphbpy $\left.)\right]^{+}$cation in $\left[\operatorname{Ir}(\mathrm{ppy})_{2^{-}}\right.$ (Naphbpy) $\left[\mathrm{PF}_{6}\right]$ (ellipsoids plotted at $30 \%$ probability level and $\mathrm{H}$ atoms omitted). Selected bond parameters: Ir1-C21 = 2.007(6), Ir1-C32= 2.019(6), Ir1-N4 = 2.037(5), Ir1-N3=2.064(5), Ir1-N1=2.150(5), Ir1$\mathrm{N} 2=2.215(5) \AA ; \mathrm{N} 1-\mathrm{r} 1-\mathrm{N} 2=75.60(18), \mathrm{C} 21-\operatorname{Ir} 1-\mathrm{N} 3=79.9(2), \mathrm{C} 32-$ $\operatorname{lr} 1-\mathrm{N} 4=80.4(2)^{\circ}$. 
deformation is associated with a face-to-face $\pi$-interaction between the 2-naphthyl unit and the phenyl ring of one of the cyclometallated ligands (Fig. 2).

\section{Dynamic behaviour of $\left[\operatorname{Ir}(\mathrm{ppy})_{2}(\mathrm{Naphbpy})\right]^{+}$in solution}

In $\left[\operatorname{Ir}\left(\mathrm{C}^{\wedge} \mathrm{N}\right)_{2}\left(\mathrm{~N}^{\wedge} \mathrm{N}\right)\right]^{+}$derivatives in which the $\mathrm{N}^{\wedge} \mathrm{N}$ ligand is a 6phenyl-substituted bipyridine (Phbpy), the phenyl group undergoes hindered rotation at room temperature on the NMR timescale. ${ }^{37-40}$ In these complexes, the ${ }^{1} \mathrm{H}$ NMR spectra at $295 \mathrm{~K}$ show broad signals only for the ortho- and meta-protons of the 6phenyl substituent and, upon cooling, only these signals are affected. At $295 \mathrm{~K}$, the ${ }^{1} \mathrm{H}$ NMR spectrum of a $\mathrm{CD}_{2} \mathrm{Cl}_{2}$ solution of $\left[\operatorname{Ir}(\mathrm{ppy})_{2}(\mathrm{Naphbpy})\right]\left[\mathrm{PF}_{6}\right]$ exhibits very broad signals for the 2naphthyl protons (not all are observed) and broadened signals for the protons of the orthometallated ring $\mathrm{C}$ (top spectrum in Fig. 3). This is consistent with dynamic behaviour involving the ring $\mathrm{C}$ and $\mathrm{G}$ domains (see Scheme 1 for ring labels). Rings $\mathrm{C}$ and $\mathrm{G}$ correspond to those involved in the intra-cation face-toface $\pi$-stacking (Fig. 1 and 2), and their resonances for most of the ${ }^{13} \mathrm{C}$ nuclei are not resolved in the ${ }^{13} \mathrm{C}$ NMR spectrum at 295 $\mathrm{K}$, but are resolved at $210 \mathrm{~K}$. In contrast, at $295 \mathrm{~K}$, the signals for protons in the bipyridine (rings $\mathrm{E}$ and $\mathrm{F}$ ) and phenylpyridine rings $\mathrm{A}, \mathrm{B}$ and $\mathrm{D}$ are well resolved.

On cooling from $295 \mathrm{~K}$ to $210 \mathrm{~K}$, signals for the protons in bpy rings $\mathrm{E}$ and $\mathrm{F}$ and orthometallated ring A remain largely unaffected, with the exception of the effects of signal overlap (Fig. 3). The broad signals for orthometallated ring $\mathrm{C}$ are resolved at $210 \mathrm{~K}$ into two sets of signals with relative integrals $2: 1$. This is illustrated in Fig. 4; the signal for the minor component of $\mathrm{H}^{\mathrm{C} 6}$ coincides with the signal at $\delta 5.32 \mathrm{ppm}$ for residual $\mathrm{CDHCl}_{2}$. Fig. 3 reveals that the two multiplets for $\mathrm{H}^{\mathrm{B} 5}$ and $\mathrm{H}^{\mathrm{D} 5}$ initially broaden upon cooling. Analysis of the COSY, HMQC and HMBC spectra recorded at $295 \mathrm{~K}$ and $210 \mathrm{~K}$ reveals that each of the signals for $\mathrm{H}^{\mathrm{B} 6}, \mathrm{H}^{\mathrm{D} 6}$ and $\mathrm{H}^{\mathrm{D} 3}$ splits into two doublets (relative integrals $2: 1$ ).

The spectroscopic data are consistent with the $\left[\operatorname{Ir}(p p y)_{2}\right.$ (Naphbpy) $]^{+}$cation existing in two conformations at low temperature by virtue of the position of the 2-naphthyl

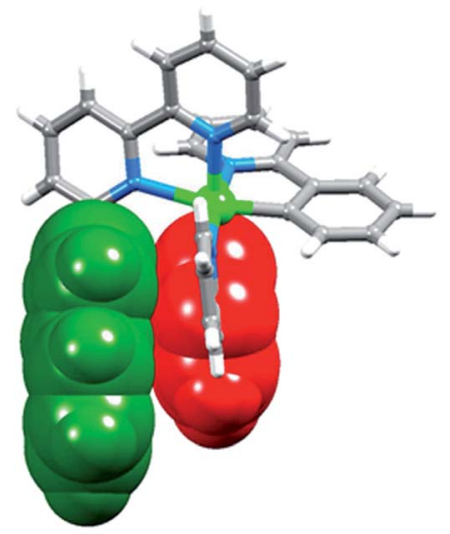

Fig. 2 Intra-cation face-to-face $\pi$-stacking of the 2 -naphthyl unit (green) with the phenyl ring (red) of one ppy ${ }^{-}$ligand in $\Lambda^{-}$ $\left[\operatorname{lr}(\text { ppy })_{2}(\text { Naphbpy) }]^{+}\right.$.

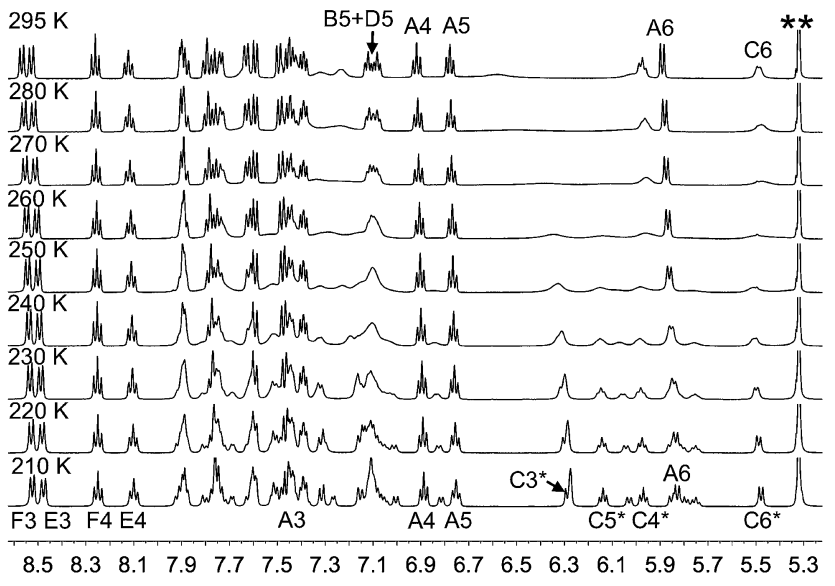

Fig. 3 Variable temperature ${ }^{1} \mathrm{H}$ NMR $\left(500 \mathrm{MHz}, \mathrm{CD}_{2} \mathrm{Cl}_{2}\right)$ spectra of $\left[\operatorname{lr}(\text { ppy })_{2}(\mathrm{Naphbpy})\right]\left[\mathrm{PF}_{6}\right]\left(* *=\right.$ residual $\left.\mathrm{CDHCl}_{2}\right)$. See Scheme 1 and Fig. 5 for atom labelling. Chemical shifts in $\partial / \mathrm{ppm}$.

substituent with respect to the cyclometallated ring $\mathrm{C}$. The $2 \mathrm{D}$ VT-NMR spectra were not consistent with rotation of the 2naphthyl group, and we propose that the dynamic behaviour involves a change in conformation by internal rotation of the bpy ligand. Conformer 1 in Fig. 5a corresponds to the crystallographically determined structure, with the 2-naphthyl unit (rings G) lying over the cyclometallated ring C. Twisting around the inter-ring bond of the bpy ligand generates conformer 2 in which the 2-naphthyl unit retains the stacking interaction over ring $\mathrm{C}$ but adopts a different relative $\pi$-stacked arrangement. Fig. 5b shows the optimized geometry calculated for conformer 2 using DFT calculations (see below).

\section{Electrochemical and photophysical properties}

The electrochemical behaviour of $\left[\operatorname{Ir}(\mathrm{ppy})_{2}(\mathrm{Naphbpy})\right]\left[\mathrm{PF}_{6}\right]$ in $\mathrm{CH}_{2} \mathrm{Cl}_{2}$ solution was investigated by cyclic voltammetry. A quasi-reversible oxidation, assigned to an iridium-centred process, occurs at $+0.83 \mathrm{~V}$ (with respect to $\mathrm{Fc} / \mathrm{Fc}^{+}$), which is similar to those reported for $\left[\operatorname{Ir}(\mathrm{ppy})_{2}(\mathrm{bpy})\right]\left[\mathrm{PF}_{6}\right](+0.84 \mathrm{~V})^{39}$ and $\left[\operatorname{Ir}(\mathrm{ppy})_{2}(\mathrm{Phbpy})\right]\left[\mathrm{PF}_{6}\right](+0.81 \mathrm{~V})^{\mathbf{1 4}}$ in DMF. A second unidentified species is observed after oxidation of the metal complex, the

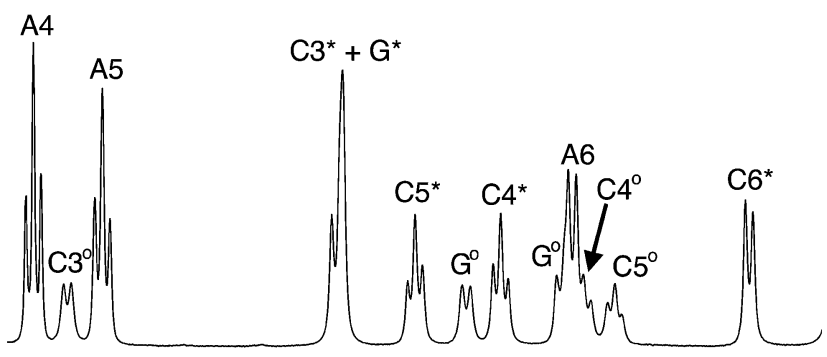

$\begin{array}{llllllllllllllll}6.9 & 6.8 & 6.7 & 6.6 & 6.5 & 6.4 & 6.3 & 6.2 & 6.1 & 6.0 & 5.9 & 5.8 & 5.7 & 5.6 & 5.5 & 5.4\end{array}$

Fig. 4 Part of the ${ }^{1} \mathrm{H}$ NMR $\left(500 \mathrm{MHz}, \mathrm{CD}_{2} \mathrm{Cl}_{2}\right)$ spectrum of $\left[\operatorname{lr}(\mathrm{ppy})_{2^{-}}\right.$ (Naphbpy)][PF 6 at $210 \mathrm{~K}$ (expansion of lowest trace in Fig. 3). See Scheme 1 and Fig. 5 for atom labelling. ${ }^{*}=$ major conformer; ${ }^{\circ}=$ minor conformer. Chemical shifts in $\partial / \mathrm{ppm}$. 
(a)

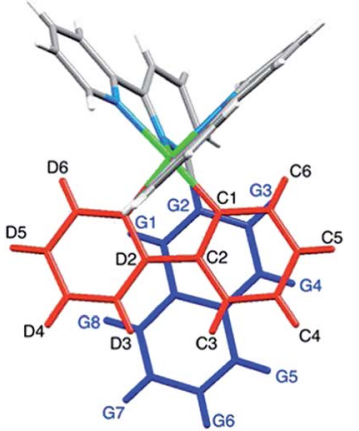

(b)

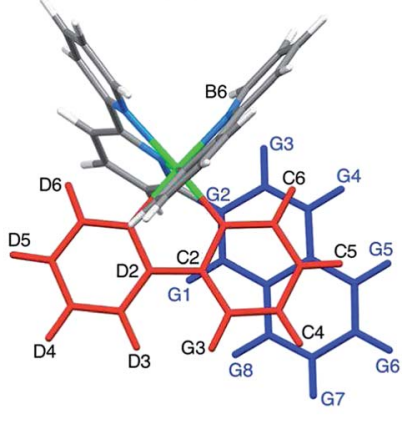

Fig. 5 Ring orientations and phenyl ring carbon atom labelling in (a) conformer 1 (X-ray structure) and (b) conformer 2 (DFT-optimized geometry) of $\left[\operatorname{lr}(\text { ppy })_{2}(\text { Naphbpy })\right]^{+}$.

origins of which are unknown (see Fig. S1 in the ESI + ). On the other hand, the quasi-reversible reduction wave at $-1.85 \mathrm{~V}$ is assigned to a ligand-based process. The electrochemical band gap $\left(E_{1 / 2}^{\mathrm{ox}}-E_{1 / 2}^{\mathrm{red}}\right)$ of $2.68 \mathrm{~V}$ compares with $2.61 \mathrm{~V}$ for $\left[\operatorname{Ir}(\text { ppy })_{2}(\mathrm{bpy})\right]\left[\mathrm{PF}_{6}\right]^{39}$ and $2.60 \mathrm{~V}$ for $\left[\operatorname{Ir}(\mathrm{ppy})_{2}(\mathrm{Phbpy})\right]\left[\mathrm{PF}_{6}\right] .^{14}$

The absorption spectrum of $\left[\operatorname{Ir}(\mathrm{ppy})_{2}(\mathrm{Naphbpy})\right]\left[\mathrm{PF}_{6}\right]$ (Fig. 6a) is dominated by a broad and intense, ligand-centred (LC) band at $264 \mathrm{~nm}$ assigned to spin-allowed $\pi \rightarrow \pi^{*}$ transitions involving both the cyclometallating and the ancillary ligands. The less intense broad absorption at $387 \mathrm{~nm}$ is attributed to transitions with mixed metal-to-ligand (MLCT) and ligand-to-ligand (LLCT) charge transfer character. Finally, the weak band observed in the spectra above $450 \mathrm{~nm}$ is due to direct spin-forbidden transitions from the singlet ground state $\left(\mathrm{S}_{0}\right)$ to the first triplet excited states of the complex, enabled by the high spin-orbit coupling constant of the iridium metal core $\left(\zeta_{\text {Ir }}=3909 \mathrm{~cm}^{-1}\right) \cdot{ }^{19}$

Excitation at $275 \mathrm{~nm}$ produces a broad, structureless emission centred at $598 \mathrm{~nm}$ (Fig. 6b). The band shape is consistent with there being significant MLCT character in the emitting state. ${ }^{19}$ The emission maximum recorded for $\left[\operatorname{Ir}(\mathrm{ppy})_{2}(\mathrm{Naphbpy})\right]\left[\mathrm{PF}_{6}\right]$ is almost identical to those reported for $\left[\operatorname{Ir}(\mathrm{ppy})_{2}(\mathrm{bpy})\right]\left[\mathrm{PF}_{6}\right]\left(\lambda_{\max }^{\mathrm{em}}=594 \mathrm{~nm}, \mathrm{MeCN}^{39}\right.$ and $\left[\operatorname{Ir}(\mathrm{ppy})_{2}(\mathrm{Phbpy})\right]\left[\mathrm{PF}_{6}\right]\left(\lambda_{\max }^{\mathrm{em}}=595 \mathrm{~nm}, \mathrm{MeCN}\right){ }^{18}$ The PLQY and
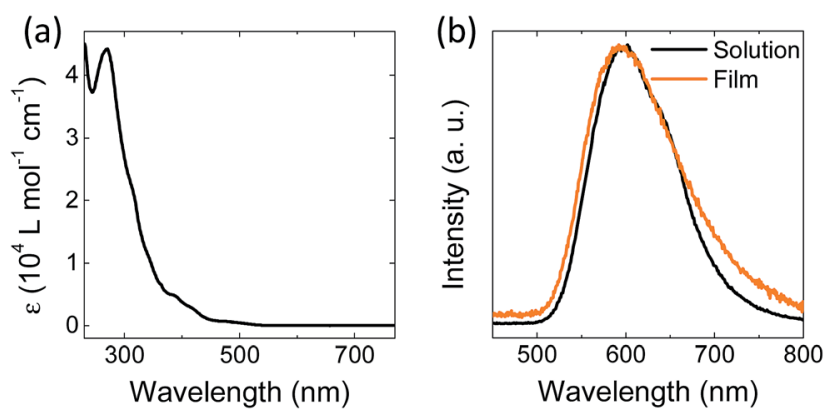

Fig. 6 (a) Absorption spectrum of $\left[\operatorname{lr}(\mathrm{ppy})_{2}(\mathrm{Naphbpy})\right]\left[\mathrm{PF}_{6}\right]\left(\mathrm{CH}_{2} \mathrm{Cl}_{2}\right.$, $\left.5 \times 10^{-5} \mathrm{~mol} \mathrm{dm}^{-3}\right)$, and (b) emission spectrum in solution $\left(\mathrm{CH}_{2} \mathrm{Cl}_{2}\right.$, $\left.1.00 \times 10^{-5} \mathrm{~mol} \mathrm{dm}^{-3}, \lambda_{\text {exc }}=275 \mathrm{~nm}\right)$ and in solid film $(100 \mathrm{~nm}$ thick film on quartz, $\lambda_{\text {exc }}=310 \mathrm{~nm}$ ). the emission lifetime $(\tau)$ were determined in argon-degassed $\mathrm{CH}_{2} \mathrm{Cl}_{2}$ solutions of $\left[\operatorname{Ir}(\mathrm{ppy})_{2}(\mathrm{Naphbpy})\right]\left[\mathrm{PF}_{6}\right]$. The PLQY and $\tau$ values recorded for $\left[\operatorname{Ir}(\mathrm{ppy})_{2}(\mathrm{Naphbpy})\right]\left[\mathrm{PF}_{6}\right](7.7 \%$ and $148 \mathrm{~ns}$, respectively) are lower than those reported in de-aerated MeCN solution for $\left[\operatorname{Ir}(\mathrm{ppy})_{2}(\mathrm{bpy})\right]\left[\mathrm{PF}_{6}\right](14 \%$ and $430 \mathrm{~ns}){ }^{39}$

Photoluminescence in the solid state was measured on a 100 $\mathrm{nm}$ thick film (Fig. 7b) obtained by spin coating a solution of the complex mixed with the ionic liquid (IL) 1-butyl-3-methylimidazolium hexafluoridophosphate $[\mathrm{BMIM}]\left[\mathrm{PF}_{6}\right]$ on a quartz substrate (the molar ratio complex:IL was $4: 1$ ). The IL was added to mimic the formulation of the active layer in a LEC (see below). The emission spectrum in thin film consists of a broad emission centred at $596 \mathrm{~nm}$ that mostly matches the band observed in solution, thus confirming the charge transfer nature of the luminescence. The measured PLQY was $10.2 \%$, a value smaller than those obtained for the analogous complexes $\left[\operatorname{Ir}(\mathrm{ppy})_{2}(\mathrm{bpy})\right]\left[\mathrm{PF}_{6}\right](34 \%)^{39}$ and $\left[\operatorname{Ir}(\mathrm{ppy})_{2}(\mathrm{Phbpy})\right]\left[\mathrm{PF}_{6}\right](21 \%){ }^{14}$ The origin of this reduction in PLQY is commented upon in the next section.

\section{Theoretical calculations}

To gain further insight into the structural, electrochemical and photophysical properties, the molecular and electronic structures of the $\left[\operatorname{Ir}(\mathrm{ppy})_{2}(\mathrm{Naphbpy})\right]^{+}$cation, in both ground and excited states, were investigated by performing DFT calculations at the B3LYP/(6-31G**+LANL2DZ) level in the presence of the solvent $\left(\mathrm{CH}_{2} \mathrm{Cl}_{2}\right)$.

Geometry optimization of $\left[\operatorname{Ir}(\mathrm{ppy})_{2} \text { (Naphbpy) }\right]^{+}$in the ground electronic state $\left(\mathrm{S}_{0}\right)$ leads to the two conformers depicted in Fig. 5. Conformer 1 corresponds to that observed in the crystal structure (Fig. 1). Even considering the differences to be expected between the calculated geometry (in $\mathrm{CH}_{2} \mathrm{Cl}_{2}$ solution) and the crystal structure due to the different media, calculations

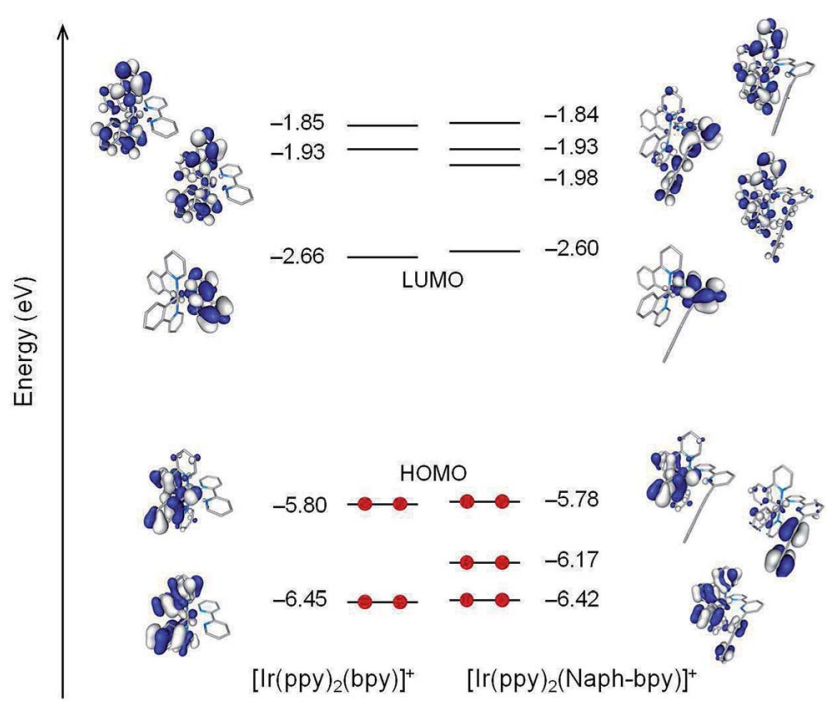

Fig. 7 Schematic diagram showing the electron density contours (0.03 a.u.) and energies calculated for the highest-occupied and lowest-unoccupied molecular orbitals of $\left[\operatorname{lr}(\text { ppy })_{2}(\text { bpy })\right]^{+}$and $\left[\operatorname{lr}(\text { ppy })_{2}(\text { Naphbpy })\right]^{+}$. Hydrogen atoms are omitted. 
predict geometric parameters in good accord with the experimental X-ray data (see Table S1 in the ESI $\dagger$ ). For instance, the values computed for the bite angle of the ancillary $\left(73.9^{\circ}\right)$ and the cyclometallating $\left(80.1\right.$ and $\left.80.0^{\circ}\right)$ ligands agree well with the X-ray values $\left(75.60(18), 79.9(2)\right.$ and $80.4(2)^{\circ}$, respectively). In agreement with experiment, the $\mathrm{ppy}^{-}$ligands are close to planar whereas the bpy ligand presents a dihedral $\mathrm{N}(1)-\mathrm{C}(5)-\mathrm{C}(6)-\mathrm{N}(2)$ angle of $17.5^{\circ}\left(\mathrm{X}\right.$-ray value $\left.=14.4^{\circ}\right)$ to accommodate the pendant 2-naphthyl group. The 2-naphthyl unit is twisted around the $\mathrm{C}(10)-\mathrm{C}(11)$ bond by $57.5^{\circ}(\mathrm{N}(2)-\mathrm{C}(10)-\mathrm{C}(11)-\mathrm{C}(20)$ dihedral angle) slightly underestimating the $\mathrm{X}$-ray value $\left(61.1^{\circ}\right)$. Calculations correctly reproduce the face-to-face $\pi$-stacking between the 2-naphthyl group and the phenyl ring of the adjacent ppy ligand. The influence of the crystal packing could explain the difference between the value calculated for the bond distance $\operatorname{Ir}-\mathrm{N}(2)(2.356 \AA)$ and the X-ray value (2.215(5) $\mathrm{\AA})$, as N(2) belongs to the pyridine to which the pendant 2-naphthyl group is attached.

Conformer 2 is mostly isoenergetic with conformer 1 , the energy difference being only $0.09 \mathrm{kcal} \mathrm{mol}^{-1}$. It mainly differs from conformer 1 in the negative value $\left(-20.8^{\circ}\right)$ of the $\mathrm{N}(1)-\mathrm{C}(5)-\mathrm{C}(6)-\mathrm{N}(2)$ dihedral angle, which leads to a different $\pi$-stacked arrangement of the 2-naphthyl group (Fig. 5). The interconversion between conformers 1 and 2 implies the internal rotation of the bpy ligand around the inter-ring $\mathrm{C}(5)-\mathrm{C}(6)$ bond and is limited by a barrier of only $1.12 \mathrm{kcal}$ $\mathrm{mol}^{-1}$ through a transition state in which the bpy ligand is mostly planar $\left(\mathrm{N}(1)-\mathrm{C}(5)-\mathrm{C}(6)-\mathrm{N}(2)=-1.1^{\circ}\right.$, Fig. $\left.\mathrm{S} 2 \dagger\right)$. The small interconversion barrier justifies the dynamic behavior observed in solution from the NMR data for $\left[\operatorname{Ir}(p p y)_{2}\right.$ (Naphbpy) $]^{+}$(see above).

Fig. 7 displays the atomic orbital compositions calculated for the highest-occupied (HOMO-2 to HOMO) and lowest-unoccupied (LUMO to LUMO+3) molecular orbitals of the $\left[\operatorname{Ir}(\mathrm{ppy})_{2}(\mathrm{Naphbpy})\right]^{+}$cation, together with those obtained for the $\left[\operatorname{Ir}(\text { ppy })_{2}(\text { bpy })\right]^{+}$archetype. The MOs sketched for $\left[\operatorname{Ir}(p p y)_{2}{ }^{-}\right.$ (Naphbpy)] $]^{+}$correspond to those computed for conformer 1 . Identical compositions and energies that differ by less than 0.02 $\mathrm{eV}$ are obtained for conformer 2. As expected, the MOs calculated for $\left[\operatorname{Ir}(\mathrm{ppy})_{2}(\mathrm{Naphbpy})\right]^{+}$and $\left[\operatorname{Ir}(\mathrm{ppy})_{2}(\mathrm{bpy})\right]^{+}$present similar topologies and appear at close energies (Fig. 7).

The almost identical HOMO energies are in good agreement with the oxidation potentials measured for $\left[\operatorname{Ir}(\mathrm{ppy})_{2}(\mathrm{Naphbpy})\right]^{+}$ $(+0.83 \mathrm{~V})$ and $\left[\operatorname{Ir}(\text { ppy })_{2}(\mathrm{bpy})\right]^{+}(+0.84 \mathrm{~V})$, and the slightly higher $(0.04 \mathrm{eV})$ HOMO-LUMO gap predicted for the former is in accord with the slightly greater $(0.07 \mathrm{~V})$ electrochemical gap reported for this complex. For both cations, the HOMO is composed of a mixture of $\operatorname{Ir}(\mathrm{III}) \mathrm{d}_{\pi}$ orbitals $\left(\mathrm{t}_{2 \mathrm{~g}}\right)$ and phenyl $\pi$ orbitals with some contribution from the pyridine rings of the cyclometallating ligands, whereas the LUMO corresponds to the $\pi^{*}$ LUMO of the bpy ligand. Therefore, if emission originates from the triplet state associated with the HOMO $\rightarrow$ LUMO excitation, similar wavelengths and photophysical properties are to be expected for both complexes. However, it is worth mentioning the presence in $\left[\operatorname{Ir}(\text { ppy })_{2}(\text { Naphbpy) }]^{+}\right.$of two MOs, the HOMO-1 and the LUMO+2, that are mainly localized on the pendant 2-naphthyl group. Transitions originating from the
HOMO-1 of $\left[\operatorname{Ir}(\mathrm{ppy})_{2}(\mathrm{Naphbpy})\right]^{+}$have no equivalence in $\left[\operatorname{Ir}(\text { ppy })_{2}(\mathrm{bpy})\right]^{+}$and may appear at lower energies than those resulting from the HOMO-1 in the latter.

The nature of the low-lying triplet states was first investigated by performing time-dependent DFT (TD-DFT) calculations at the optimized geometry of the ground state $\left(\mathrm{S}_{0}\right)$. Table 1 lists the vertical excitation energies and electronic descriptions computed for the four lowest-lying triplet excited states of $\left[\operatorname{Ir}(\mathrm{ppy})_{2}(\mathrm{Naphbpy})\right]^{+}$. A close correspondence, both in energy and electronic nature, can be made between states $\mathrm{T}_{1}(2.46 \mathrm{eV})$, $\mathrm{T}_{3}(2.71 \mathrm{eV})$ and $\mathrm{T}_{4}(2.78 \mathrm{eV})$ of $\left[\operatorname{Ir}(\mathrm{ppy})_{2}(\mathrm{Naphbpy})\right]^{+}$and the $\mathrm{T}_{1}$, $\mathrm{T}_{2}$ and $\mathrm{T}_{3}$ states of $\left[\operatorname{Ir}(\mathrm{ppy})_{2}(\mathrm{bpy})\right]^{+}$calculated at $2.43,2.75$ and $2.80 \mathrm{eV}$, respectively. For both systems, the lowest-lying triplet state $\left(\mathrm{T}_{1}\right)$ is mainly defined by the HOMO $\rightarrow$ LUMO excitation, which has a mixture of metal-to-ligand and ligand-to-ligand charge transfer $\left({ }^{3} \mathrm{MLCT} /{ }^{3} \mathrm{LLCT}\right)$ character. States $\mathrm{T}_{3}$ and $\mathrm{T}_{4}$ of $\left[\operatorname{Ir}(\text { ppy })_{2}(\mathrm{Naphbpy})\right]^{+}$are defined by transitions from the HOMO to the LUMO+1 and LUMO+2 and have ligand-centred $\left({ }^{3} \mathrm{LC}\right)$ character involving the $\mathrm{C}^{\wedge} \mathrm{N}$ ligands as it is also the case for the $\mathrm{T}_{2}$ and $\mathrm{T}_{3}$ states of $\left[\operatorname{Ir}(\mathrm{ppy})_{2}(\mathrm{bpy})\right]^{+}$.

The $\mathrm{T}_{2}$ state of $\left[\operatorname{Ir}(\mathrm{ppy})_{2}(\mathrm{Naphbpy})\right]^{+}$is singular as it has no correspondence in the archetype $\left[\operatorname{Ir}(\mathrm{ppy})_{2}(\mathrm{bpy})\right]^{+}$cation. Despite its large multiconfigurational character, it mainly involves electron excitations between MOs centred on the pendant 2naphthyl group. It therefore has a ${ }^{3} \mathrm{LC}$ character largely localized on the 2-naphthyl substituent of the ancillary ligand. The presence of this singular $\mathrm{T}_{2}$ state reduces the energy difference between the first and second triplet states to $0.17 \mathrm{eV}$ in $\left[\operatorname{Ir}(\text { ppy })_{2}(\text { Naphbpy })\right]^{+}$. As the energy of both states will decrease after geometrical relaxation, the small gap between them opens the possibility that $T_{2}$ becomes competitive with $T_{1}$.

To study this possibility, the two lowest triplet states of $\left[\operatorname{Ir}(\mathrm{ppy})_{2}(\mathrm{Naphbpy})\right]^{+}$were reexamined by optimizing their geometries at the TD-DFT level. The optimized structure of $\mathrm{T}_{1}$ presents small but noticeable differences compared with that obtained for the ground state (Table $\mathrm{S} 1 \dagger)$. The $\mathrm{Ir}-\mathrm{N}(2)$ bond shortens from 2.356 to $2.249 \AA$ in passing from $S_{0}$ to $T_{1}$ and the bpy domain becomes more planar (the $\mathrm{N}(1)-\mathrm{C}(5)-\mathrm{C}(6)-\mathrm{N}(2)$ dihedral angle changes from 17.5 to $11.0^{\circ}$ ). These changes point to a stronger interaction between the Ir core and the ancillary ligand in $T_{1}$. For the $T_{2}$ state, the coordination sphere of the iridium center remains mostly unaffected compared to $S_{0}$ (Table $\mathrm{S} 1 \dagger$ ), and the most important changes concern the pendant 2-naphthyl group (Fig. S3 $\dagger$ ). The intramolecular $\pi$ stacking between the 2-naphthyl group and the phenyl ring of the adjacent ppy $^{-}$ligand is preserved in both excited states.

Fig. 8 displays the unpaired-electron spin density distributions calculated for the $T_{1}$ and $T_{2}$ states after full-geometry relaxation. For $\mathrm{T}_{1}$, the spin density distribution (Ir: 0.48, ppy: 0.49, bpy: 1.01, Naph: 0.02 e) perfectly matches the topology of the HOMO $\rightarrow$ LUMO excitation (Fig. 7) and indicates an electron transfer from the $\operatorname{Ir}(\mathrm{ppy})_{2}$ moiety to the bpy ligand. It therefore corroborates the mixed ${ }^{3} \mathrm{MLCT} /{ }^{3} \mathrm{LLCT}$ character of the $\mathrm{T}_{1}$ state. For $\mathrm{T}_{2}$, the spin density distribution (Ir: 0.01 , ppy: 0.03 , bpy: 0.15, Naph: $1.81 \mathrm{e}$ ) is mostly localized over the 2-naphthyl unit and confirms the ${ }^{3} \mathrm{LC}$ (2-naphthyl) character predicted above for this triplet (Table 1). The different electronic nature 
Table 1 Lowest triplet excited states calculated at the TD-DFT B3LYP/(6-31G**+LANL2DZ) level for complex $\left[\operatorname{lr}(\mathrm{ppy})_{2}(\mathrm{Naphbpy})\right]^{+}$in $\mathrm{CH} \mathrm{H}_{2} \mathrm{Cl} \mathrm{L}_{2}$ solution. Vertical excitation energies $(E)$, dominant monoexcitations with contributions (within parentheses) greater than $15 \%$, nature of the electronic transition and description of the excited state are summarized. $\mathrm{H}$ and L denote HOMO and LUMO, respectively

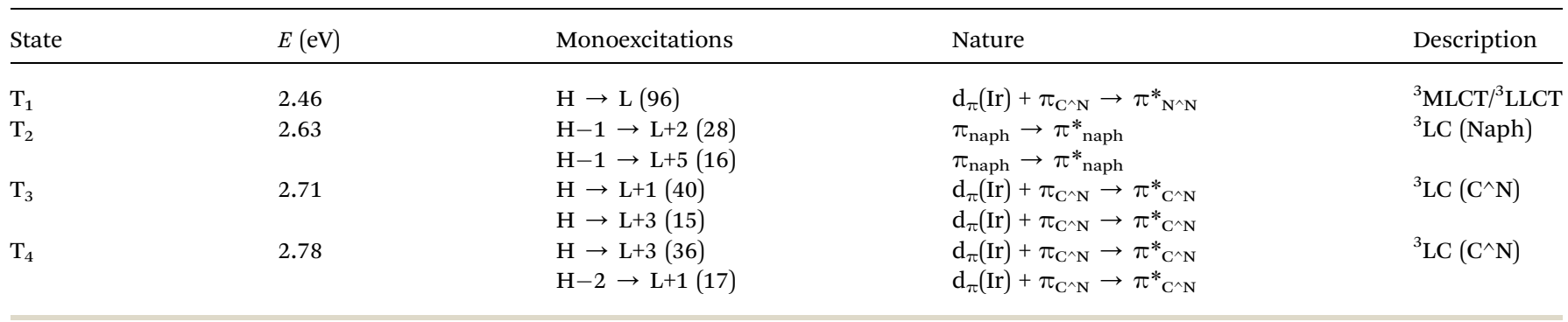
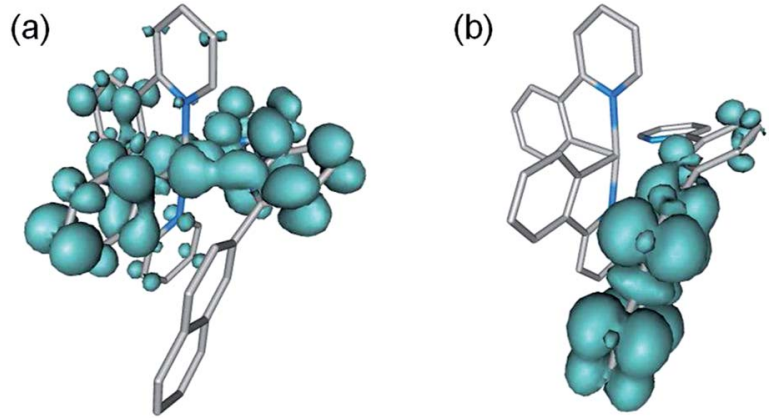

Fig. 8 Unpaired-electron spin-density contours (0.002 a.u.) calculated for the fully-relaxed $T_{1}$ (a) and $T_{2}$ (b) triplet states of $\left[\operatorname{lr}(\text { ppy })_{2}(\text { Naphbpy })\right]^{+}$.

obtained for $T_{1}$ and $T_{2}$ justifies the changes computed for their respective geometries. The important point is that, after fullgeometry relaxation at the TD-DFT level, the ${ }^{3} \mathrm{MLCT} /{ }^{3} \mathrm{LLCT} \mathrm{T}_{1}$ state continues to be the lowest-lying triplet, although it is only $0.09 \mathrm{eV}$ below the $\mathrm{T}_{2}$ state (adiabatic energy difference $=$ electronic energy difference between the excited states at their respective mínimum-energy equilibrium geometries).

Calculations therefore suggest that the emitting $\mathrm{T}_{1}$ state of $\left[\operatorname{Ir}(\text { ppy })_{2}(\text { Naphbpy) }]^{+}\right.$has a mixed ${ }^{3} \mathrm{MLCT} /{ }^{3}$ LLCT nature in good agreement with the broad and unstructured aspect of the emission band (Fig. 6b). However, the ${ }^{3} \mathrm{LC} \mathrm{T}_{2}$ triplet resides at energies low enough to compete with $\mathrm{T}_{1}$ during the population process. This could be the reason for the lower PLQY measured for $\left[\operatorname{Ir}(\mathrm{ppy})_{2}(\mathrm{Naphbpy})\right]^{+}$compared to $\left[\operatorname{Ir}(\mathrm{ppy})_{2}(\mathrm{bpy})\right]^{+}$, for which no low-energy state equivalent to $\mathrm{T}_{2}$ state is available. The vertical emission energy calculated for $T_{1}$ at its optimized minimum-energy geometry $(621 \mathrm{~nm})$ is in reasonably good accord with the emission maximum observed experimentally (598 nm).

\section{Electroluminescent devices}

The electroluminescence (EL) of the $\left[\operatorname{Ir}(\mathrm{ppy})_{2}(\mathrm{Naphbpy})\right]\left[\mathrm{PF}_{6}\right]$ complex was investigated in double layer LECs consisting of a $100 \mathrm{~nm}$ thick layer of the complex spin-coated from acetonitrile (2 wt\%) onto an $80 \mathrm{~nm}$ thick film of poly(3,4-ethylenedioxythiophene):poly(styrenesulfonate) (PEDOT:PSS). The PEDOT:PSS layer was deposited on a pre-patterned indium-tinoxide (ITO)-coated glass substrate with the twofold purpose of flattening the ITO anode surface and enhancing hole injection from the ITO to the HOMO of the complex. Prior to spin-coating, the IL $[\mathrm{BMIM}]\left[\mathrm{PF}_{6}\right]$ was added to the $\left[\operatorname{Ir}(\mathrm{ppy})_{2}(\mathrm{Naphbpy})\right]\left[\mathrm{PF}_{6}\right]$ solution (the molar ratio complex : IL was $4: 1$ ), in order to enhance the ionic mobility of the emitting layer and thus reducing the turn-on time of the device. ${ }^{41}$ Finally, an aluminum cathode (100 $\mathrm{nm}$ ) was vacuum-deposited onto the emitting layer through a shadow mask. Spin-coating was done in ambient atmosphere; the base pressure during the cathode evaporation was $10^{-6}$ mbar. The thickness of the films was determined with an Ambios XP-1 profilometer. Thin film photoluminescence spectra and quantum yields were measured with a Hamamatsu C9920-02 absolute pl quantum yield measurement system. Lifetime data were obtained by applying pulsed currents and monitoring the voltage and simultaneously the luminance by a true colour sensor MAZeT (MTCSICT Sensor) using a lifetime test system designed by Botest (Botest OLT OLED Lifetime-Test System). The photocurrent was calibrated using a Minolta LS-100 luminance meter. Electroluminescence spectra were recorded using an Avantis fiber optics photospectrometer. Devices were not encapsulated and were characterized inside a glovebox. The LECs were driven using a pulsed current (block wave, $1000 \mathrm{~Hz}$; duty cycle 50\%; peak current per pulse $100 \mathrm{~A} \mathrm{~m}^{-2}$; average current $50 \mathrm{~A} \mathrm{~m}^{-2}$ ) and their performances were recorded continuously over time (Fig. 9a-b).

Due to the pulsed current driving, the LECs turn on instantly delivering more than $100 \mathrm{~cd} \mathrm{~m}^{-2}$ after being biased for $1 \mathrm{~s}$. In the first measured hour the device luminance reaches $200 \mathrm{~cd}$ $\mathrm{m}^{-2}$ and then grows steadily until reaching $\sim 330 \mathrm{~cd} \mathrm{~m}^{-2}$ where it remains stable for the duration of the experiment (350 hours) (Fig. 9a). The average voltage follows the opposite trend, starting from values above $5 \mathrm{~V}$ at the beginning of the measurements, and progressively decaying and subsequently stabilizing at about 2.7 V (Fig. 9a). This indicates a reduction of the device resistance, which is consistent with the formation of doped zones in the emitting layer near the electrodes. ${ }^{42}$ As mentioned above, the device lifetime was monitored for more than 350 hours, showing high luminance and essentially no degradation. Accelerated lifetime testing in LECs is unfortunately not trivial as higher temperature testing would influence the ionic motion and therefore the local distribution of ions, which alters the device performance. Testing at higher luminance levels can also 
(a)

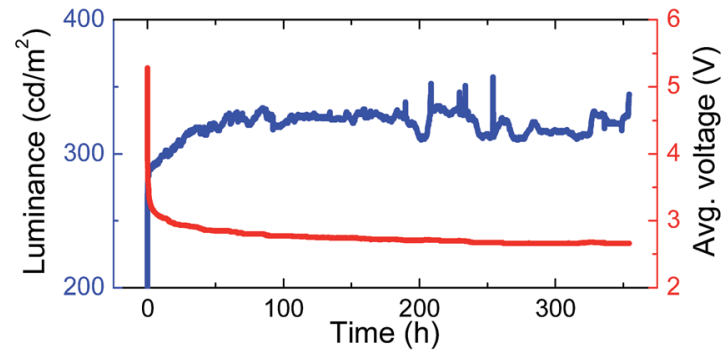

(b)
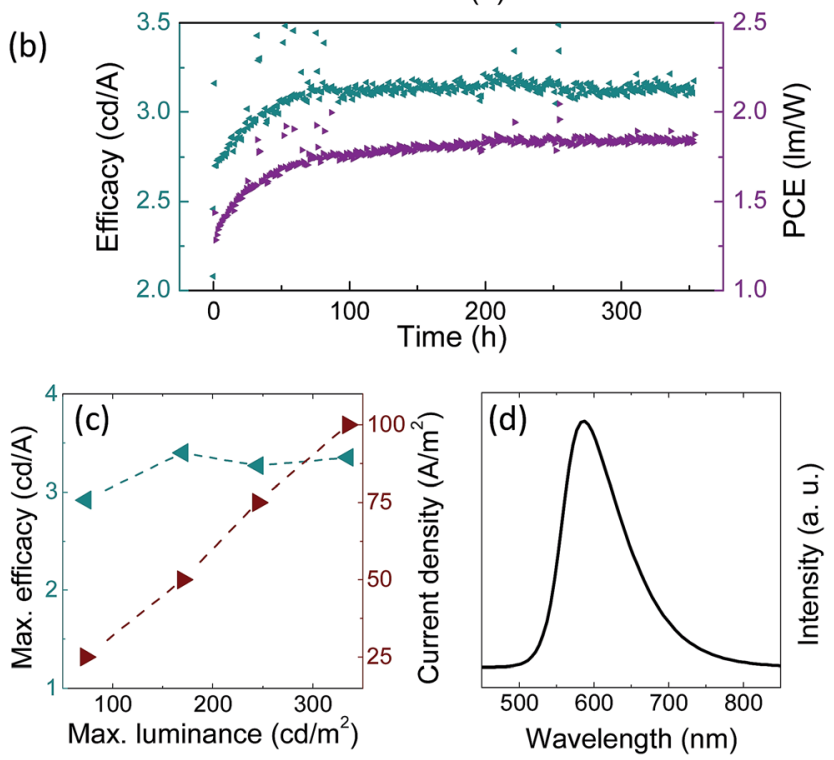

Fig. 9 Typical device performance data. (a) Luminance (blue)/voltage (red) and (b) efficacy (green)/power (purple) conversion efficiency vs. time for a LEC biased with a pulsed current using a block wave at a frequency of $1000 \mathrm{~Hz}$, a duty cycle of $50 \%$ and a peak current density of $100 \mathrm{~A} \mathrm{~m}^{-2}$. (c) Maximum efficacy (green) and correspondent current density (red) as a function of the peak luminance measured. (d) Electroluminescent spectra of the $\left[\operatorname{Ir}(\mathrm{ppy})_{2}(\mathrm{Naphbpy})\left[\mathrm{PF}_{6}\right]\right.$ complex in the LEC.

not be easily modeled to lower luminance driving conditions because with higher luminance the current density is increased and leads to an increase in the doped region and, as a result, to an increase in the luminescence quenching. Due to this we were not able to extrapolate the lifetime but it is expected to be at least 10 times this initial phase leading to a stability of 3000 hours. Such a very good stability is consistent with an efficient intramolecular interaction able to stabilize the excited state of the complex and thus enhancing the device lifetime. ${ }^{\mathbf{1 4}}$ The corresponding efficacy was stable at an average value of $3.2 \mathrm{~cd}$ $\mathrm{A}^{-1}$ and a power conversion efficiency of $1.8 \mathrm{~lm} \mathrm{~W}^{-1}$ when considering the measured potential drop at the device contacts (Fig. 9b). A series of devices was prepared and measured at different peak current density, from 25 to $100 \mathrm{~A} \mathrm{~m}^{-2}$. The device efficacy is essentially independent of the luminance level and scales linearly with the applied current density over this range, meaning that the LEC can be used at the desired light output without altering its efficiency (Fig. 9c). The electroluminescent spectra appears as a broad peak centered at $588 \mathrm{~nm}$ (Fig. 9d), very similar to what is observed in the photoluminescence spectra (Fig. 6b) and in analogous complexes reported previously. ${ }^{\mathbf{1 4}}$

\section{Conclusions}

A new charged bis-cyclometallated iridium(III) complex, $\left[\operatorname{Ir}(\text { ppy })_{2}(\right.$ Naphbpy) $]\left[\mathrm{PF}_{6}\right]$, incorporating a 2-naphthyl substituent in the 6-position of the ancillary $2,2^{\prime}$-bipyridine ligand has been presented. The pendant 2-naphthyl group $\pi$-stacks with the adjacent cyclometallating ligand and protects the complex from undesirable degradation reactions. The complex presents a broad, structureless emission band centred around 595-600 $\mathrm{nm}$ both in solution and in thin film that points to an emission from a triplet state with a large charge transfer character. Theoretical calculations confirm the MLCT/LLCT nature of the lowest-energy emitting triplet and predict a second low-lying triplet state of LC nature associated with the 2-naphthyl unit. The presence of this triplet is invoked as a plausible reason for the relatively low photoluminescence quantum yields displayed by the complex. Despite this shortcoming, the complex gives rise to bright and very stable solid-state light-emitting electrochemical cells. Instantaneous light turn-on and luminances above $300 \mathrm{~cd} \mathrm{~m}^{-2}$ are obtained for LECs using this complex. Furthermore, no decay in luminance is observed for more than 350 hours, demonstrating their extraordinary stability.

\section{Acknowledgements}

We thank the Swiss National Science Foundation, the University of Basel, the European Union (CELLO, STRP 248043), the European Research Council (Advanced Grant 267816 LiLo), the Spanish Ministry of Economy and Competitiveness MINECO (MAT2011-24594 and CTQ2012-31914), the Generalitat Valenciana (PROMETEO/2012/053) and European Feder funds (CTQ2012-31914) for financial support. A.P. acknowledges the MINECO for a FPI grant.

\section{Notes and references}

1 Y. Shirota and H. Kageyama, Chem. Rev., 2007, 107, 9531010.

2 S. O. Jeon, S. E. Jang, H. S. Son and J. Y. Lee, Adv. Mater., 2011, 23, 1436-1441.

3 H. Sasabe and J. Kido, Eur. J. Org. Chem., 2013, 7653-7663.

4 M. Stössel, J. Staudigel, F. Steuber, J. Simmerer and A. Winnacker, Appl. Phys. A: Mater. Sci. Process., 1999, 68, 387-390.

5 C. D. Muller, A. Falcou, N. Reckefuss, M. Rojahn, V. Wiederhirn, P. Rudati, H. Frohne, O. Nuyken, H. Becker and K. Meerholz, Nature, 2003, 421, 829-833.

6 L. Duan, L. Hou, T.-W. Lee, J. Qiao, D. Zhang, G. Dong, L. Wang and Y. Qiu, J. Mater. Chem., 2010, 20, 6392-6407.

7 C. Zhong, C. Duan, F. Huang, H. Wu and Y. Cao, Chem. Mater., 2010, 23, 326-340.

8 Q. B. Pei, G. Yu, C. Zhang, Y. Yang and A. J. Heeger, Science, 1995, 269, 1086-1088. 
9 J. C. deMello, N. Tessler, S. C. Graham and R. H. Friend, Phys. Rev. B: Condens. Matter Mater. Phys., 1998, 57, 12951-12963.

10 J. D. Slinker, J. A. DeFranco, M. J. Jaquith, W. R. Silveira, Y. W. Zhong, J. M. Moran-Mirabal, H. G. Craighead, H. D. Abrũa, J. A. Marohn and G. G. Malliaras, Nat. Mater., 2007, 6, 894-899.

11 J. K. Lee, D. S. Yoo, E. S. Handy and M. F. Rubner, Appl. Phys. Lett., 1996, 69, 1686-1688.

12 J. D. Slinker, J. Rivnay, J. S. Moskowitz, J. B. Parker, S. Bernhard, H. D. Abruna and G. G. Malliaras, J. Mater. Chem., 2007, 17, 2976-2988.

13 C. Rothe, C.-J. Chiang, V. Jankus, K. Abdullah, X. Zeng, R. Jitchati, A. S. Batsanov, M. R. Bryce and A. P. Monkman, Adv. Funct. Mater., 2009, 19, 2038-2044.

14 R. D. Costa, E. Ortí, H. J. Bolink, S. Graber, C. E. Housecroft and E. C. Constable, Adv. Funct. Mater., 2010, 20, 1511-1520.

15 L. J. Soltzberg, J. D. Slinker, S. Flores-Torres, D. A. Bernards, G. G. Malliaras, H. D. Abruña, J.-S. Kim, R. H. Friend, M. D. Kaplan and V. Goldberg, J. Am. Chem. Soc., 2006, 128, 7761-7764.

16 J. D. Slinker, J.-S. Kim, S. Flores-Torres, J. H. Delcamp, H. D. Abruna, R. H. Friend and G. G. Malliaras, J. Mater. Chem., 2007, 17, 76-81.

17 R. D. Costa, E. Ortí, H. J. Bolink, S. Graber, C. E. Housecroft and E. C. Constable, J. Am. Chem. Soc., 2010, 132, 5978-5980.

18 H. J. Bolink, E. Coronado, R. D. Costa, E. Ortí, M. Sessolo, S. Graber, K. Doyle, M. Neuburger, C. E. Housecroft and E. C. Constable, Adv. Mater., 2008, 20, 3910-3913.

19 R. D. Costa, E. Ortí, H. J. Bolink, F. Monti, G. Accorsi and N. Armaroli, Angew. Chem., Int. Ed., 2012, 51, 8178-8211.

20 F. Chung, C. Tisné, T. Lecourt, F. Dardel and L. Micouin, Angew. Chem., Int. Ed., 2007, 46, 4489-4491.

21 J. G. Park and Y. Jahng, Bull. Korean Chem. Soc., 1998, 19, 436-439.

22 G. E. Schneider, H. J. Bolink, E. C. Constable, C. D. Ertl, C. E. Housecroft, A. Pertegas, J. A. Zampese, A. Kanitz, F. Kessler and S. B. Meier, Dalton Trans., 2014, 1961-1964.

23 I. Bruker Analytical X-ray Systems, APEX2, version 2 User Manual, M86-E01078, Madison, WI, 2006.

24 G. M. Sheldrick, Acta Crystallogr., Sect. A: Found. Crystallogr., 2007, 64, 112-122.

25 C. F. Macrae, I. J. Bruno, J. A. Chisholm, P. R. Edgington, P. McCabe, E. Pidcock, L. Rodriguez-Monge, R. Taylor, J. Van De Streek and P. A. Wood, J. Appl. Crystallogr., 2008, 41, 466-470.

26 I. J. Bruno, J. C. Cole, P. R. Edgington, M. Kessler, C. F. Macrae, P. McCabe, J. Pearson and R. Taylor, Acta Crystallogr., Sect. B: Struct. Sci., 2002, 58, 389-397.

27 M. J. Frisch, G. W. Trucks, H. B. Schlegel, G. E. Scuseria, M. A. Robb, J. R. Cheeseman, G. Scalmani, V. Barone, B. Mennucci, G. A. Petersson, H. Nakatsuji, M. Caricato,
X. Li, H. P. Hratchian, A. F. Izmaylov, J. Bloino, G. Zheng, J. L. Sonnenberg, M. Hada, M. Ehara, K. Toyota, R. Fukuda, J. Hasegawa, M. Ishida, T. Nakajima, Y. Honda, O. Kitao, H. Nakai, T. Vreven, J. A. Montgomery, Jr, J. E. Peralta, F. Ogliaro, M. Bearpark, J. J. Heyd, E. Brothers, K. N. Kudin, V. N. Staroverov, R. Kobayashi, J. Normand, K. Raghavachari, A. Rendell, J. C. Burant, S. S. Iyengar, J. Tomasi, M. Cossi, N. Rega, N. J. Millam, M. Klene, J. E. Knox, J. B. Cross, V. Bakken, C. Adamo, J. Jaramillo, R. Gomperts, R. E. Stratmann, O. Yazyev, A. J. Austin, R. Cammi, C. Pomelli, J. W. Ochterski, R. L. Martin, K. Morokuma, V. G. Zakrzewski, G. A. Voth, P. Salvador, J. J. Dannenberg, S. Dapprich, A. D. Daniels, Ö. Farkas, J. B. Foresman, J. V. Ortiz, J. Cioslowski and D. J. Fox, Gaussian 09, Revision D.01, Gaussian, Inc., Wallingford, CT, 2009.

28 C. Lee, W. Yang and R. G. Parr, Phys. Rev. B: Condens. Matter Mater. Phys., 1988, 37, 785-789.

29 A. D. Becke, J. Chem. Phys., 1993, 98, 5648-5652.

30 M. M. Francl, W. J. Pietro, W. J. Hehre, J. S. Binkley, M. S. Gordon, D. J. DeFrees and J. A. Pople, J. Chem. Phys, 1982, 77, 3654-3665.

31 P. J. Hay and W. R. Wadt, J. Chem. Phys., 1985, 82, 299-310. 32 J. Tomasi and M. Persico, Chem. Rev., 1994, 94, 2027-2094.

33 C. S. Cramer and D. G. Truhlar, Solvent Effects and Chemical Reactivity, Kluwer, 1996, pp. 1-80.

34 J. Tomasi, B. Mennucci and R. Cammi, Chem. Rev., 2005, 105, 2999-3094.

35 F. Kröhnke, Synthesis, 1976, 1.

36 F. Neve, A. Crispini, S. Campagna and S. Serroni, Inorg. Chem., 1999, 38, 2250-2258.

37 E. Baranoff, H. J. Bolink, E. C. Constable, M. Delgado, D. Haussinger, C. E. Housecroft, M. K. Nazeeruddin, M. Neuburger, E. Orti, G. E. Schneider, D. Tordera, R. M. Walliser and J. A. Zampese, Dalton Trans., 2013, 1073-1087.

38 A. M. Bünzli, H. J. Bolink, E. C. Constable, C. E. Housecroft, M. Neuburger, E. Ortí, A. Pertegás and J. A. Zampese, Eur. J. Inorg. Chem., 2012, 2012, 3780-3788.

39 R. D. Costa, E. Ortí, D. Tordera, A. Pertegás, H. J. Bolink, S. Graber, C. E. Housecroft, L. Sachno, M. Neuburger and E. C. Constable, Adv. Energy Mater., 2011, 1, 282-290.

40 D. Tordera, A. M. Bünzli, A. Pertegás, J. M. JunqueraHernández, E. C. Constable, J. A. Zampese, C. E. Housecroft, E. Ortí and H. J. Bolink, Chem.-Eur. J., 2013, 19, 8597-8609.

41 S. T. Parker, J. D. Slinker, M. S. Lowry, M. P. Cox, S. Bernhard and G. G. Malliaras, Chem. Mater., 2005, 17, 3187-3190.

42 S. B. Meier, S. van Reenen, B. Lefevre, D. Hartmann, H. J. Bolink, A. Winnacker, W. Sarfert and M. Kemerink, Adv. Funct. Mater., 2013, 23, 3531-3538. 